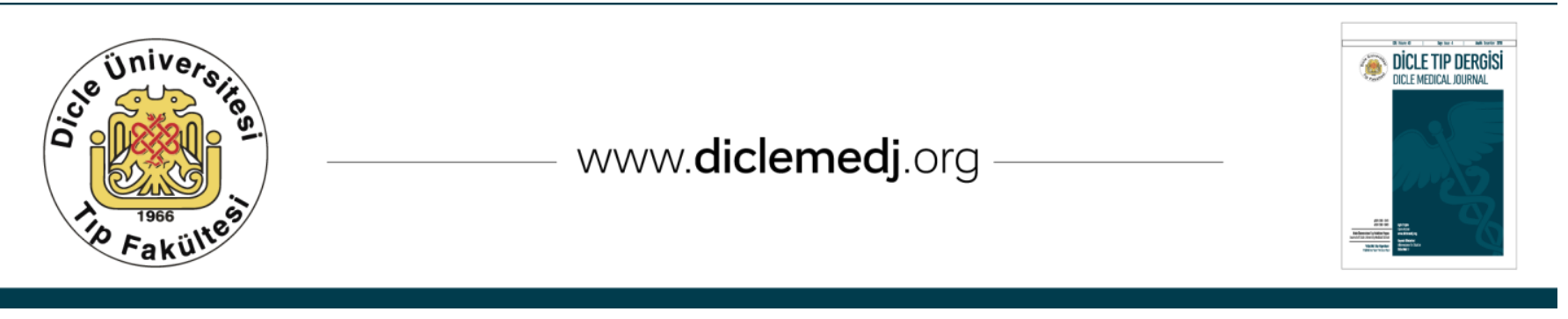

Case Report / Olgu Sunumu

\title{
Atypical Optic Nerve Sheath Menengioma Mimics Like Optic Neuritis; A case report
}

\author{
Umay Güvenç¹, Gözde Orman², Gülten Sungur³ ${ }^{3}$,Selma Uzman \\ 1 Univ of Health Sciences, Ankara Training and Researching Hospital, Department of Opthalmology, Ankara, Turkey, ORCID: 0000-0002-8993-1674 \\ 1 Univ of Health Sciences, Ankara Training and Researching Hospital, Department of Opthalmology, Ankara, Turkey, ORCID: 0000-0001-5223-3816 \\ 1 Univ of Health Sciences, Ankara Training and Researching Hospital, Department of Opthalmology, Ankara, Turkey, 0RCID: 0000-0002-4440-0941 \\ 1 Univ of Health Sciences, Ankara Training and Researching Hospital, Department of Opthalmology, Ankara, Turkey, ORCID: 0000-0002-4967-7325
}

Received: 06.03.2019; Revised: 24.04.2019; Accepted: 20.06.2019

\section{Abstract}

A 40-years old female patient applied with complaining of a progressive vision loss for 3 months. Systemic symptoms were; headache, tingling in her hands and feet and pain during eye movements. Visual acuity was hand motion on the right eye, 20/20 on the Snellen chart on the left. There was relative afferent pupillary defect on the right eye. In fundoscopic examination, disc edema was met on the right eye and left eye's fundus examination was normal.

A prolongation of p100 wave latency in the Visual Evoked Potentials examination and total visual field defect on automated perimetry test were seen on the right eye. The patient was hospitalized with a pre-diagnosis of optic neuritis. Orbita Magnetic Rezonans was reported the optic nerve sheath menengioma (ONSM). Atypical clinical presentation of an ONSM case that mimiced as optic neuritis, extended to the optic chiasm and lead to a progressive visual loss in a period of 3 months is presented. It is crucial to recognize atypical ONSM cases by the guidence of imaging techniques.

Keywords: Optic nerve sheath meningioma, MRI, Optic neuritis. 


\section{Optik Nöriti Taklit Eden Atipik Optik Sinir Kılıf Menenjiomu; Olgu Sunumu}

Öz

40 yaşında kadın hasta 3 aydır progresif görme kaybı şikayeti ile kliniğimize başvurdu. Baş ağrısı, el ve ayaklarında karıncalanma ve göz hareketlerinde ağrı mevcuttu. Oftalmolojik muayenesinde, görme keskinliği sağ göze el hareketleri, sol göz Snellen çizelgesinde 20/20 düzeyindeydi. Sağ gözde rölatif afferentpupildefekti mevcuttu. Fundoskopik incelemede sağ gözde disk ödemi saptandı, sol gözde fundus muayenesi normaldi.

Uyarılmış vizüel potansiyel incelemesinde sağ gözde p100 latansında uzama ve otomatik perimetri testinde total görme alanı defekti görüldü. Hasta optik nörit ön tanısı ile yatırıldı. Magnetikrezönans görüntülemede T2AG ve FLAIR sekanslarında, optik sinir boyunca tam uzunlukta optik sinir kllıf hemanjiyomu (OSKH) ile uyumlu kontrast tutulumu fark edildi. Bu bulgular ışığında hastaya OSKM tanısı kondu.

Optik nöriti taklit eden, optik kiazmaya kadar uzayan ve 3 aylık bir süreçte progresif görme kaybına neden olan bir OSKH vakasının atipik klinik sunumu sunulmuștur. Atipik OSKH vakalarının, görüntüleme tekniklerinin rehberliği ile tanınması yanlış tanı tedaviyi önlemek adına çok önemlidir.

Anahtar kelimeler: Optik sinir kılıf menenjiomu, MR, Optik nörit.

\section{INTRODUCTION}

Optic nerve sheath menengiomas(ONSM), are benign tumors thatoriginates from arachnoid cells of the optic nerve sheath. It is reported to be the most common optic nerve tumor coming after gliomas and it constitutes $2 \%$ of all orbital tumors, $1-2 \%$ of all menengiomas as well 1 . Primer ONSM is more common than the seconder ONSM which originates from the intracranial area and reaches to the orbita. Although ONSM may occur in all ages, it is most common in middle-aged females ${ }^{2}$.

In this case report a remarkable atypical ONSM case that mimiced optic neuritis, extended to the optic chiasm and lead to a progressive visual loss in a period of 3 months is present. It is crucial to recognize atypical ONSM cases by the guidence of imaging techniquesin order to administer appropriate treatment modalities.

\section{CASE}

A 40-years old female patient applied to eye clinic with complaining of a progressive vision loss for 3 months. She was working in a textile company and there was no significant feature in her medical history. Systemic symptoms were; headache, tingling in her hands and feet and pain during eye movements. In her ophtalmological examination, visual acuity was just enough to recognise hand motion on the right eye, 20/20 on the Snellen chart on the left. Intraocular pressure was measured with Goldmannapplanation tonometer as $12 \mathrm{mmHg}$ on the right and $14 \mathrm{mmHg}$ on the left. Anterior segment examination was normal in both eyes. There was relative afferent pupillary defect(RAPD) on the right eye.

In fundoscopic examination, disc edema was met on the right eye and left eye's fundus examination was totally normal (Figure 1). A prolongation of p100 wave latency in the Visual Evoked Potentials(VEP) examination and a total visual field defect on automated perimetry test were seen on the right eye whereas both tests were noted normal for the left (Figure 2). The patient was hospitalized with a prediagnosis of optic neuritis and routine blood tests and imagingswere proceeded. There was novaluable indications except hypothyroidism in blood tests. The patient's contrast-enhenced cranial MRI was reported normal. In contrast enhanced orbit MRI T2AG and FLAIR,a hyperintense thickening along the optic nerve and a full lenght contrast uptake along the optic nerve sheath were noticed, however no 
contrast uptake was reported over the central part of the optic nerve sheath and the optic nerve (Figure 3 ). In the light of these findings, the patient was diagnosed as ONSM and consulted to neurosurgery. Since the extension of the tumor reached all the way through the optic nerve, operation was not recommended.
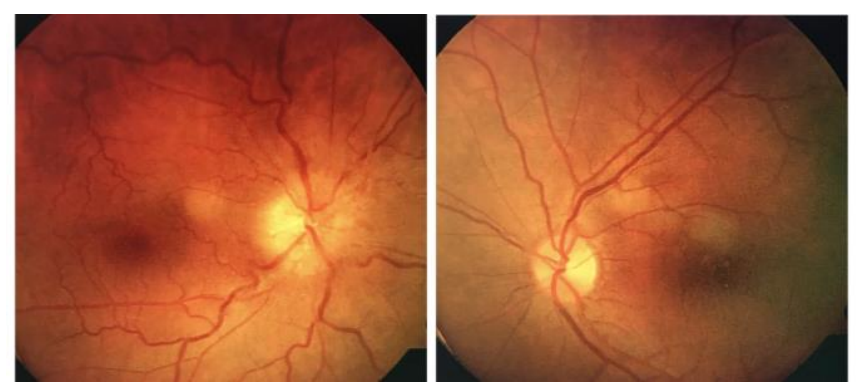

Figure 1: Optic disc edema in right fundus and normal apperence of left optic disc

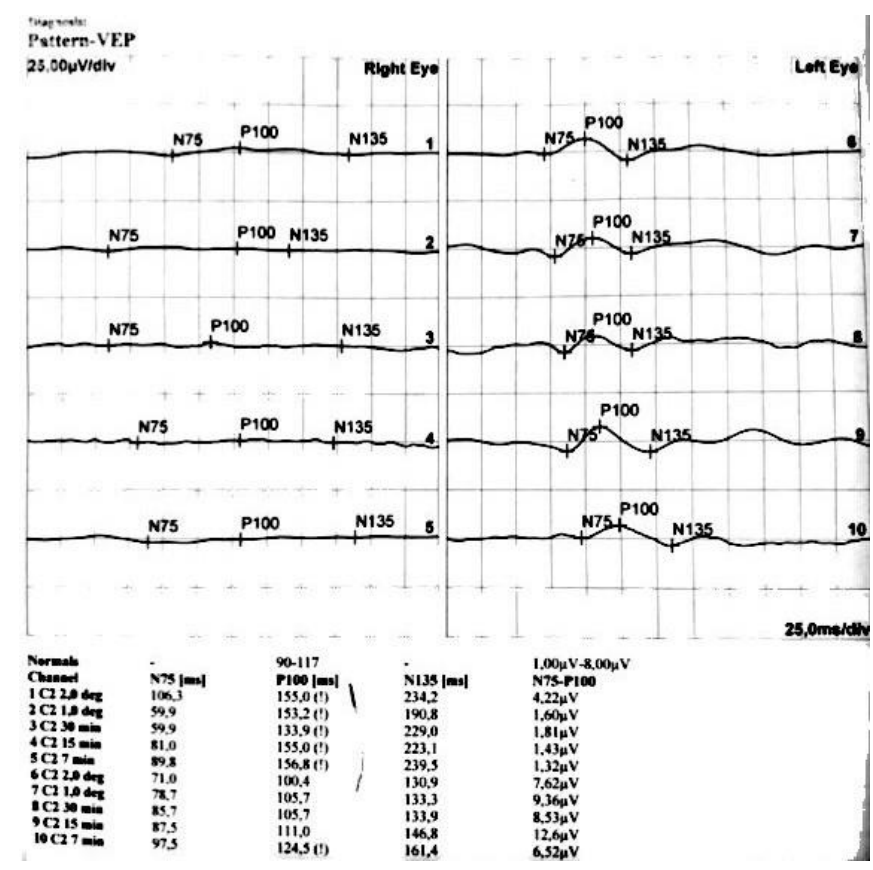

Figure 2: Prolonged of right eye in Visual Evoked Potential examination with normal lefte eye

\section{DISCUSSION}

ONSM is characterized by progresive, painless vision loss, and clinical presentation typically occurs 1-5 years after the disease onset ${ }^{3}$. The clinical triad of ONSM is known as HoytSpencer triad consisting of slowly progressive vision loss, optic atrophy and optocilliary shunt vessels ${ }^{4}$. Other clinical findings are proptosis, colour vision defects, disc edema, discomfort or pain in eye movements and rarely headache ${ }^{5}$. Though the most common visual field defect is peripheral constriction; other defects as blind spot enlargement, altitudinal visual field defect and central scotoma are have also been reported ${ }^{2}$.
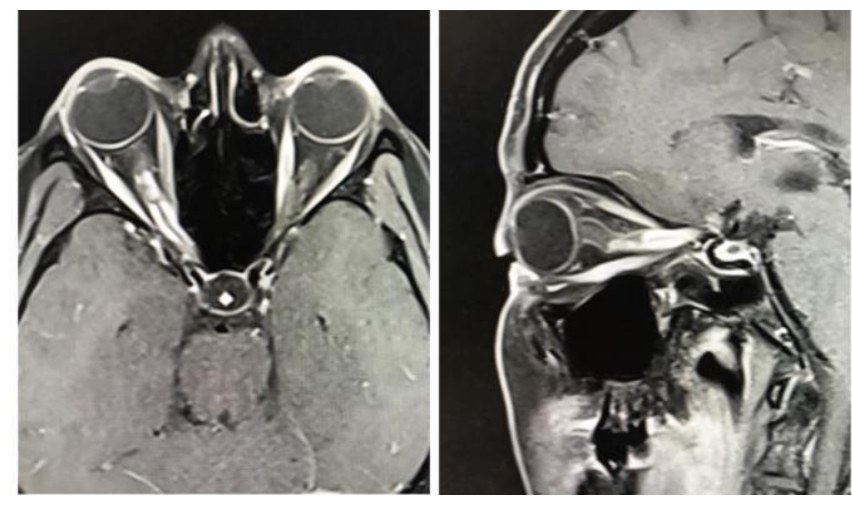

Figure 3: In contrast enhanced orbit MRI T2 scanning a hyper-intense thickening along the right optic nerve and a full lenght contrast uptake along the optic nerve sheath, however no contrast uptake over right optic nerve

Radiological findings are typically enlargement of the optic canal, thickening of the optic nerve diameter and calcification of the nerve sheath. Although CT is valuable for showing calcifications, fat supressed contrast enhanced T1 weighed MRI sequences are the goldstandard imaging methods for the diagnosis of menengioma and to detect the invasion of the tumor ${ }^{5}$.

Despite the fact that the ethiology of ONSM is not exactly understood, radiation exposure to the head is thought to be related with menengiomas ${ }^{6}$. It is reported that patients with neurofibromatosis type 2 have a $50 \%$ chance of developing menengiomas ${ }^{7}$. ONSM is thought to cause ischemic changes in the optic nerve and impairs axonal transport by affecting the pial vascular circulation mainly by mass effect 1,8 . Because of the wide variety of clinical findings and the fact that they are not always all together, the diagnosis of ONSM should be 
supported by imaging methods. Otherwise patients may be misdiagnosed as optic neuritis or ischemic optic neuropathy and wrong treatment modalities could be administered ${ }^{9}$.

The differential diagnosis of ONSM involves; optic neuritis, ischemic optic neuropathy, orbital pseudotumor, optic glioma and lymphoma. Optic gliomas are rarely calcificated tumors, in which contrast uptake is week. They are mostly seen in the first decade. Orbital pseudotumor is an idiopathic inflammatory process which responds to steroid therapy ${ }^{10}$. Optic neuritis has also a good response to steroids; but different from the others there is an acute vision loss accompanying periocular pain and RAPD. It'styhpical appearance on CT and MRI, noninvasive growth pattern, almost stable clinical presentation and irresponsiveness to steroid therapy; ONSM should come to the mind 5 .

In treatment; surgery, radiotherapy or followup are possible when ONSM is diagnosed. Patients without severe visual loss, proptosis or intracranial extension may be followed without treatment. Stereotactic radiation therapy is prefered to surgery in many cases due to diffuculties of surgical techniques and postoperative complications ${ }^{5}$.

In our case, the progressive visual loss in a short period of 3 months, the presence of painful eye movements and disc edema were the distinquishing findings rather than the typhical ONSM findings. In this case where ONSMmimiced optic neuritis, by the use of imaging techniques, a misdiagnosis and an inappropriate treatment plan was prevented.

Although the lesion of ONSM defined on MRI was extended to the optic chiasm along the optic nerve, it is surprising that the symptoms were acute and rapidly progressive. This may be because of the fact that the patient applied the clinical examination a while after the first symptoms occured.
In conclusion, ONSM cases may be diagnosed from many different clinical conditions. It is crucial to support the diagnosis with appropriate imaging techniques in order to avoid possible false diagnosises and treatment approaches and plan the optimal treatment.

Our case report was presented at 52. Turkish Ophthalmology Society National Congress between November 13-18, 2018 in Antalya.

Conflicts of interest: The authors have no conflict of interests to declare.

Financial Disclosure: The authors declared that this study has received no financial support.

\section{REFERENCES}

1. Wright J, McNab A, McDonald W. Primary optic nerve sheath meningioma. Br Ophthalmol1989; $73: 7$.

2. Saeed P, Rootman J, Nugent RA, et all. Optic nerve sheath meningiomas. Ophthalmology 2003; 110: 2019-30.

3. Wilson WB. Meningiomas of the anterior visual system. Survey of Ophthalmology 1981; 26: 109-27.

4. Miller NR. Primary tumours of the optic nerve and its sheath. Eye 2004; 18: 1026-37.

5. Shapey J, Sabin HI, Danesh-Meyer HV, Kaye AH. Diagnosis and management of optic nerve sheath meningiomas. J ClinNeurosci 2013; 20: 1045-56.

6. Mack EE, Wilson CB. Meningiomas induced by highdose cranial irradiation. Neurosurg1993; 79: 28-31.

7. Arar ZV, Vatavuk Z, Miskic B, et all. Optic Nerve Sheath Meningioma: A Case Report with 15-Year Follow-Up. Seminars in Ophthalmology 2013; 29: 5255.

8. Schick U, Jung C, Hassler WE. Primary optic nerve sheath meningiomas: a follow-up study. CenEurNeurosurg2010; 71: 126-33.

9. Mao JF, Xia XB, Tang XB, Zhang XY, Wen D. Analyses on the misdiagnoses of 25 patients with unilateral optic nerve sheath meningioma. International Journal of Ophthalmology 2016; 9: 1315-9.

10. Deftereos SP, Karagiannakis GK, Spanoudaki A, Foutzitzi SN, Prassopoulos P. Optic nerve sheath meningioma: a case report. Cases Journal 2008; 1: 423. 